\title{
The Influence of Lime Material and Nitrogen Fertilization on Reed Canary Grass Productivity, Plant Quality and Environmental Impact of Using Biomass for Energy Purposes
}

\author{
Gintaras Šiaudinis ${ }^{1}$, Algirdas Jasinskas ${ }^{2, *}$, Egidijus Šarauskis ${ }^{2}{ }^{(D}$, Regina Skuodienè $^{1}$, Regina Repšienè $^{1}$ \\ and Danutè Karčauskiené ${ }^{1}$ \\ 1 Vėžaičiai Branch of the Lithuanian Research Centre for Agriculture and Forestry, Gargždu Str. 29, Vèžaičiai, \\ LT-96216 Klaipèda, Lithuania; Gintaras.Siaudinis@lammc.lt (G.Š.); Regina.Skuodiene@lammc.lt (R.S.); \\ Regina.Repsiene@lammc.lt (R.R.); Danute.Karcauskiene@lammc.lt (D.K.) \\ 2 Institute of Agricultural Engineering and Safety, Agriculture Academy, Vytautas Magnus University, \\ Studentu 15A, Akademija, LT-53362 Kaunas, Lithuania; egidijus.sarauskis@vdu.lt \\ * Correspondence: algirdas.jasinskas@vdu.lt; Tel.: +370-612-04002
}

\section{check for} updates

Citation: Šiaudinis, G.; Jasinskas, A.; Šarauskis, E.; Skuodienè, R.; Repšienè R.; Karčauskienė, D. The Influence of Lime Material and Nitrogen Fertilization on Reed Canary Grass Productivity, Plant Quality and Environmental Impact of Using Biomass for Energy Purposes. Agronomy 2021, 11, 895. https:// doi.org/10.3390/agronomy11050895

Academic Editor: Danilo Scordia

Received: 16 April 2021

Accepted: 29 April 2021

Published: 2 May 2021

Publisher's Note: MDPI stays neutral with regard to jurisdictional claims in published maps and institutional affiliations.

Copyright: (c) 2021 by the authors. Licensee MDPI, Basel, Switzerland. This article is an open access article distributed under the terms and conditions of the Creative Commons Attribution (CC BY) license (https:// creativecommons.org/licenses/by/ $4.0 /)$.
Abstract: A field experiment with reed canary grass (Phalaris arundinacea L.) was carried out at LAMMC Vèžaičiai Branch (Western Lithuania) in 2010-2016 with the aim to evaluate the impact of liming and nitrogen on grass productivity, biomass chemical content and energetic parameters of the pellets. The site soil is the natural acidic loam Retisol ( $\mathrm{pH}$ 4.2-4.6). Reed canary grass productivity was significantly affected by the year of growing and nitrogen fertilization. The average annual dry matter (DM) yield varied from 5442 to $11,114 \mathrm{t} \mathrm{ha}^{-1}$. The highest yields were obtained using the annual rate of $120 \mathrm{~kg} \mathrm{ha}^{-1} \mathrm{~N}$ (nitrogen) fertilizers. Soil liming had a negligible effect on biomass productivity. Nitrogen utilization efficiency (NUE) varied greatly depending on the growing year and $\mathrm{N}$ fertilization rate. After analyzing the properties of reed canary grass and wood sawdust granules, it was found that the granules obtained a high density exceeding $1000 \mathrm{~kg} \mathrm{~m}^{-3} \mathrm{DM}$. The lowest calorific value of reed canary grass pellets was found to be quite high $-17.4 \mathrm{MJ} \mathrm{kg}-1 \mathrm{DM}$. All harmful emissions did not exceed the permissible values. Summarizing the results, it can be stated that reed canary grass pellets may be recommended for burning in domestic boilers.

Keywords: growing year; liming; nitrogen; reed canary grass; yield; chemical content; solid biofuel; pellets; properties; harmful emissions

\section{Introduction}

With the intensive use and depletion of fossil fuel reserves on Earth, the use of renewable energy sources is becoming increasingly important. Biomass from energy crops is one of the most important sources of renewable energy in temperate-climate countries. In addition, bioenergy is considered to be "carbon neutral energy" because during combustion it emits as much $\mathrm{CO}_{2}$ into the environment as it consumes during photosynthesis [1-4].

In order to avoid competition with traditional crops, energy crops should be grown in areas or soils where cultivation of conventional crops is less economically viable. For example, a large part of Western Lithuania is naturally covered by Fluvisols and Retisols. Soil $\mathrm{pH}$, unfavorable for plant growth, higher annual rainfall, faster leaching of nutrients into deeper soil layers, declining organic carbon and lower microbiological activity are leading to loss-making farming [5]. The use of organic and calcareous materials significantly helps to adjust the $\mathrm{pH}$ of the upper soil layer and increases its productivity. In addition to the traditional cultivation of cereals, crucifers, or legumes, some of the soils in the region can be designated for growing energy crops [6-9].

The cultivation of perennial grasses and the use of their biomass for biofuels is an important object of research in various European countries [9-11]. Grasslands have an 
advantage over short-rotation forest plantations because their biomass can be used for $7-10$ years without annual reseeding $[1,10,11]$. Of these, there are considerable prospects for tall coarse grasses that were previously used for animal feed. Because of the declining importance of animal husbandry, their biomass is also very suitable to produce solid fuels and biogas due to its suitable chemical composition and high productivity [1,10-12].

Of the many grass species studied, several researchers indicate that one of the most promising species for temperate climate in Europe and North America is reed canary grass (RCG) (Phalaris arundinacea L.) [13,14]. This grass is less demanding for growing conditions as it can grow in many soils worldwide [15-17].

Due to the adaptability of RCG to grow in highly acidic soil conditions, Kukk et al. (2011) concluded that RCG biomass yield is significantly higher when growing in Luvisol (neutral $\mathrm{pH})$ than in peatland soil $\left(\mathrm{pH}_{\mathrm{KCl}}\right.$ 2.5-4.0) [18]. Liming (use of lime material) had a positive effect on the growth of RCG biomass when growing in highly acidic peat soils [19]. However, data on how the growth and productivity of reed canary grass depend on different types of mineral soils as well as their different $\mathrm{pH}$ levels are still scarce [20,21].

The role of nitrogen and its effect on RCG productivity has been described by several Lithuanian and foreign authors [12,22,23]. Herewith, the efficiency of nitrogen is highly dependent on many factors such as soil type and water availability $[18,24]$. The research data are ambiguous on whether the use of liming material (i.e., an increase of calcium ions in soil) affects the efficiency of nitrogen fertilization $[25,26]$.

The characteristics that make perennial grasses attractive for biomass production and for various other purposes are their high yield potential, high contents of lignin and cellulose. Research on herbal plants and their use for energy purposes is carried out in many European countries and the United States. The research results for perennial grasses show that scourge millet (Panicum virgatum), elephant grass (Miscanthus giganteus), sugar cane (Arundo donax) and reed canary grass (Phalaris arundinacea) have the highest potential for due to the production of high yields [1]. Research on nontraditional herbaceous plants is being carried out in Lithuania and other countries, the results of which only confirm that this is a new, but very promising type of biofuel. Experiments with herbal plants for biofuel at the Lithuanian Institute of Agriculture started in 1997. These experiments were focused on herbaceous plants studied in Europe, the most popular of which are elephant grass and reed canary grass [27-29]. The results of calorific value, obtained in 2014, showed that the lower calorific value of elephant grass and reed canary grass dry fuel was $17.8 \mathrm{MJ} \mathrm{kg}^{-1}$ and $17.4 \mathrm{MJ} \mathrm{kg}^{-1}$, respectively. For comparison, the lower calorific value of the birch dry fuel, often used for biofuels, is $19.3 \mathrm{MJ} \mathrm{kg}^{-1}$ [29].

Thus, the first aim of our research was to estimate the role of soil liming and nitrogen application, and their possible interaction on reed canary grass productivity throughout seven successive growing seasons in Retisol. Second was to evaluate the impact of both factors on the chemical content of RCG. Third was to estimate technological parameters of RCG biomass. In addition, also it is important to study and evaluate the technologicaltechnical solutions of reed canary grass processing into solid biofuels by compressing them into pellets, to determine the most important properties of granulated biofuels and to assess the environmental impact of burning these biofuels.

\section{Methods}

\subsection{The Field Experiment Site and Design}

The field experiment with reed canary grass (Phalaris arundinacea L.) was carried out at Vèžaičiai Branch of the Lithuanian Research Centre for Agriculture and Forestry (LAMMC) (Western Lithuania, $55^{\circ} 43^{\prime} \mathrm{N}, 2^{\circ} 27^{\prime}$ E) (Figure 1) since 2009. The soil of the experimental site is a naturally acidic moraine loamy Bathygleyic Dystric Glossic Retisol (WRB, 2014) with a clay content $(<0.002 \mathrm{~mm})$ of $15.0 \%$. Before starting the experiment, soil chemical analyses (from 0-30 cm upper soil layer) were performed. Soil characteristics are as follows: $\mathrm{pH}_{\mathrm{KCl}}$ 4.25-4.85, mobile $\mathrm{P}_{2} \mathrm{O}_{5}-35-120 \mathrm{mg} \mathrm{kg}^{-1}$, mobile $\mathrm{K}_{2} \mathrm{O}-140-209 \mathrm{mg} \mathrm{kg}^{-1}$, hydrolytic acidity-21.9-62.1 mequiv $\mathrm{kg}^{-1}$. 


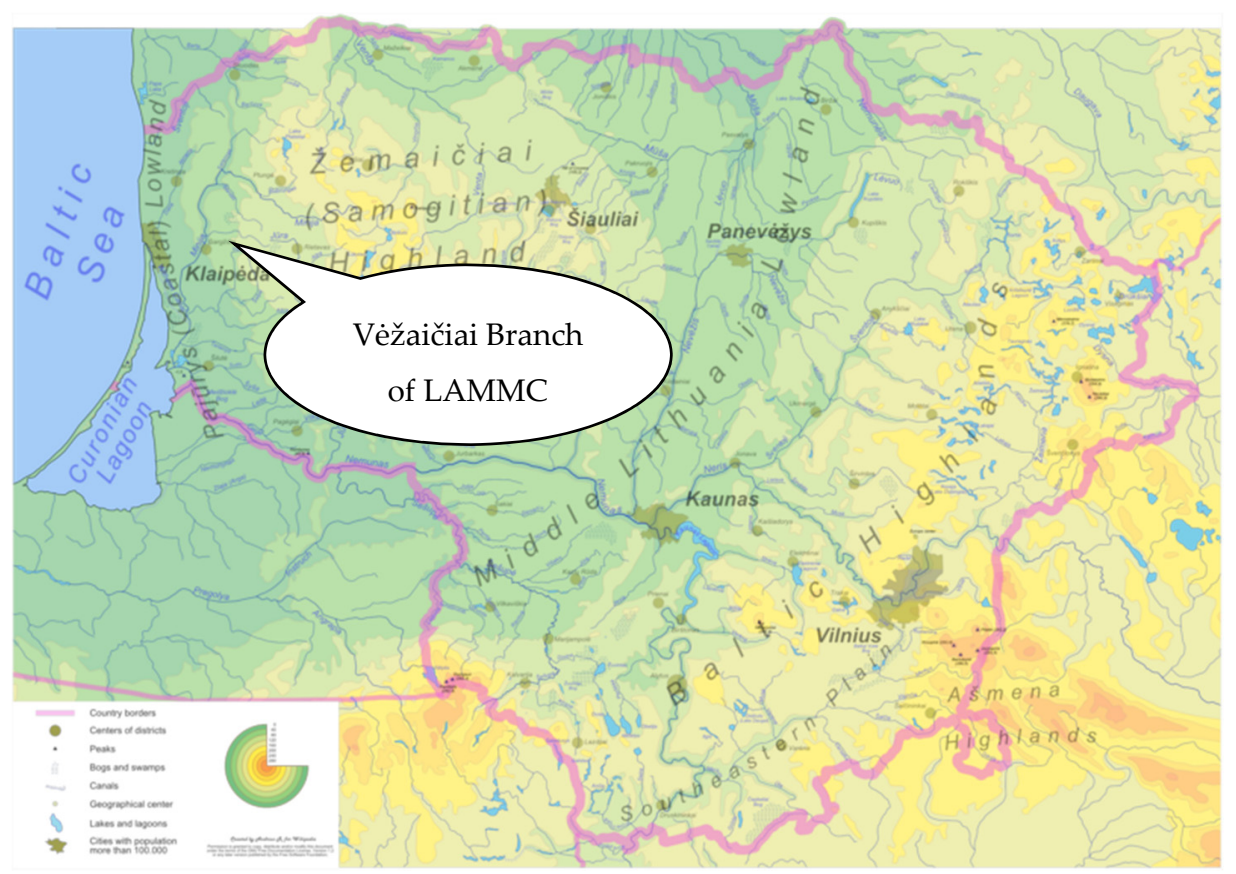

Figure 1. The location of Vèžaičiai Brach of the Lithuanian Research Centre for Agriculture and Forestry.

The experimental site was divided according to factorial design with two factors. The first factor was liming. The experimental site was divided into three strips depending on the level of liming-not limed (control), limed at $3.0 \mathrm{tha}^{-1} \mathrm{CaCO}_{3}$ and $6.0 \mathrm{CaCO}_{3}$ $\mathrm{t} \mathrm{ha}^{-1} \mathrm{CaCO}_{3}$ rates. The second factor was nitrogen fertilization. There were three nitrogen levels-N0 (not limed, control), N60 and N120. Nitrogen treatments in three replications were randomly allocated in all 3 strips. Nitrogen fertilization was performed manually. The annual rate of phosphorus $\left(\mathrm{P}_{2} \mathrm{O}_{5}\right)$ and potassium $\left(\mathrm{K}_{2} \mathrm{O}\right)$ fertilization was the same$60 \mathrm{~kg} \mathrm{ha}^{-1}$. The netto area of the treatments was $14 \mathrm{~m}^{2}$.

Dusty limestone (Opokos) was used as the liming material, which was applied before the start of the experiment in 2009. Ammonium nitrate was used as the nitrogen fertilizer. The source of phosphorus was single superphosphate, and the source of potassiumpotassium chloride.

Reed canary grass ("Chieftain") was sown on 14 July 2009 with the sowing rate of $15 \mathrm{~kg} \mathrm{ha}^{-1}$ of viable seeds. Each subsequent year, the grass yield was harvested twice per growing season - at the end of June (at full maturity stage) and the aftermath (at the end of September). The grass was harvested with a mower HEGE211B. Dry matter (DM) yield $(t$ $\mathrm{ha}^{-1}$ ) was measured by drying the grass samples to air-dry matter and then multiplying by green-grass yield.

Plant chemical analyses were performed in the LAMMC Chemical Research Laboratory (Akademija, Kèdainiai dist., Lithuania). For chemical analysis, all biomass of harvested plans was used, and plant material was chopped and milled into particles of 2-3 mm. Weight of sample-500 g. The following parameters were estimated: total carbon (C) (by method), total nitrogen (N) (by Kjeldahl method), crude fat (by Henneberg and Stohman method), crude fiber (by Van Soest method), crude ash (by weight), calorific value $\left(\mathrm{kJ} \mathrm{kg}^{-1}\right.$ ) (using a C2000 calorimeter (IKA company, Staufen, Germany).

Nitrogen utilization efficiency (NUE) was calculated according to the equation: [(DM yield with applied fertilizer $\mathrm{N}$ rate) - (DM yield in zero- $\mathrm{N})] / \mathrm{N}$ rate, where $\mathrm{N}$ - the content of $\mathrm{N}$ in $\mathrm{kg} \mathrm{ha}^{-1}$. Lime utilization efficiency (LUE) was calculated similarly: [(DM yield with liming) - (DM yield without liming)]/L rate ( $\mathrm{t}$ ha ${ }^{-1} \mathrm{CaCO}_{3}$ rate)

The nitrogen nutrition index (NNI), which indicates the sufficiency of nitrogen in plants, was calculated according to the following equation: $\mathrm{NNI}=\mathrm{N}_{\text {act }} / \mathrm{N}_{\mathrm{c}}$, where $\mathrm{N}_{\text {act }}$ is 
the actual $\mathrm{N}$ content as a percent of the dry matter of reed canary grass biomass; $\mathrm{N}_{\mathrm{c}}$ is the critical content of $\mathrm{N}\left(\mathrm{N}_{\mathrm{c}}\right)$ calculated according to the following equation: $\mathrm{Nc}=(5.35 \times \mathrm{DM}$ $\left(\mathrm{t} \mathrm{ha}^{-1}\right)^{-0.442}[30]$.

\subsection{Assessment of Biofuel Production, Energy Use and Harmful Emissions}

\subsubsection{Biofuel Production and Qualitative Parameters of the Pellets}

The chopped and milled reed canary grass biomass was granulated with a $7.5 \mathrm{~kW}$ pelletizer (Polexim, Izdebki, Poland) with a horizontal pellet production matrix with $6 \mathrm{~mm}$ holes. The productivity of pellet production was $250-300 \mathrm{~kg} \mathrm{~h}^{-1}$. The photo of milled and granulated reed canary grass is presented in Figure 2. Pine wood sawdust pellets were also produced and tested as a control.

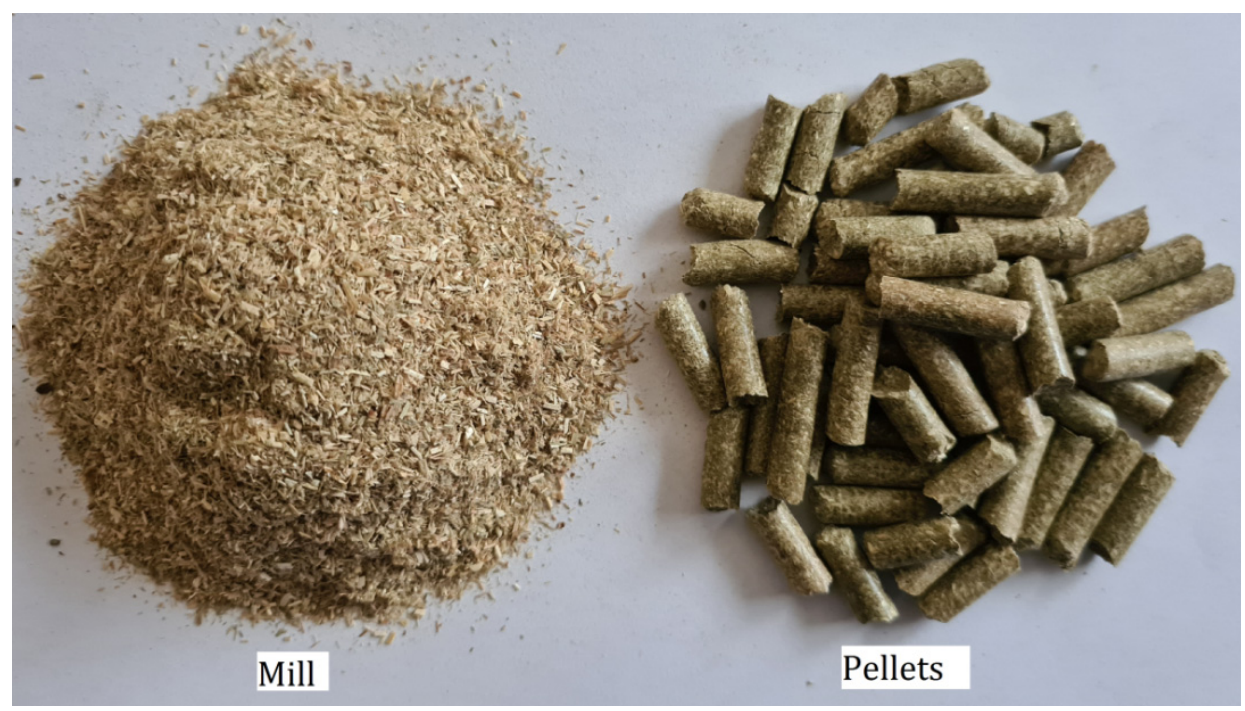

Figure 2. Mill and pellets of reed canary grass.

To determine the biometric and qualitative parameters of the biofuel pellets, they were measured (length and diameter) and weighed. Finally, the volumes and densities with their square errors were calculated. The moisture content of the pellets was determined and calculated according to the standard method [30]. The pellet volume was calculated using the pellet size (diameter and length).

The elemental composition and moisture content (\%) of plant pellets were determined at the Lithuanian Energy Institute using special equipment, testing laboratories, and devices. All studies were conducted in accordance with the current standard methodologies of Lithuania and other European Union countries [31,32].

\subsubsection{Determination of Harmful Emissions}

In order to evaluate the emission of harmful gases into the environment, such as carbon dioxide $\mathrm{CO}_{2}$, carbon monoxide $\mathrm{CO}$, nitrogen oxides $\mathrm{NOx}$ and unburned hydrocarbons $\mathrm{C}_{\mathrm{x}} \mathrm{H}_{\mathrm{y}}$ by burning various plant pellets, the produced pellets were burned in a low-capacity pellet fuel boiler in the laboratory of the Lithuanian Energy Institute. Samples of pellets from various plants (5 $\mathrm{kg}$ each) were burned for 10-15 min., and during combustion harmful gas emissions were detected and fixed with a smoke analyzer DATATEST 400 CEM (Tethys Instruments, Meylan, France) [33].

\subsection{Statistical Analysis of Experimental Data}

The obtained data for all parameters studied were statistically processed using analysis of variance (ANOVA) as a three-factor randomized block variant to determine significant differences between the means (* $p<0.05$ and ${ }^{* *} p<0.01$ ), $\operatorname{LSD}_{05}$ and $\mathrm{LSD}_{01}$ (at $95 \%$ and $99 \%$ probability levels) tests [34]. 


\section{Results and Discussion}

\subsection{Meteorological Conditions}

Meteorological parameters for the 2010-2016 vegetation period (from April to September) are presented in Figure 3. In 2010 and 2011, the weather (temperature and precipitation regime) was warm and rainy and, thus, the growing conditions for reed canary grass biomass were quite favorable with relatively good distribution of precipitation. In 2012 and 2013, during the period of intense grass growth, there was a periodical shortage of soil moisture in the upper soil layer.

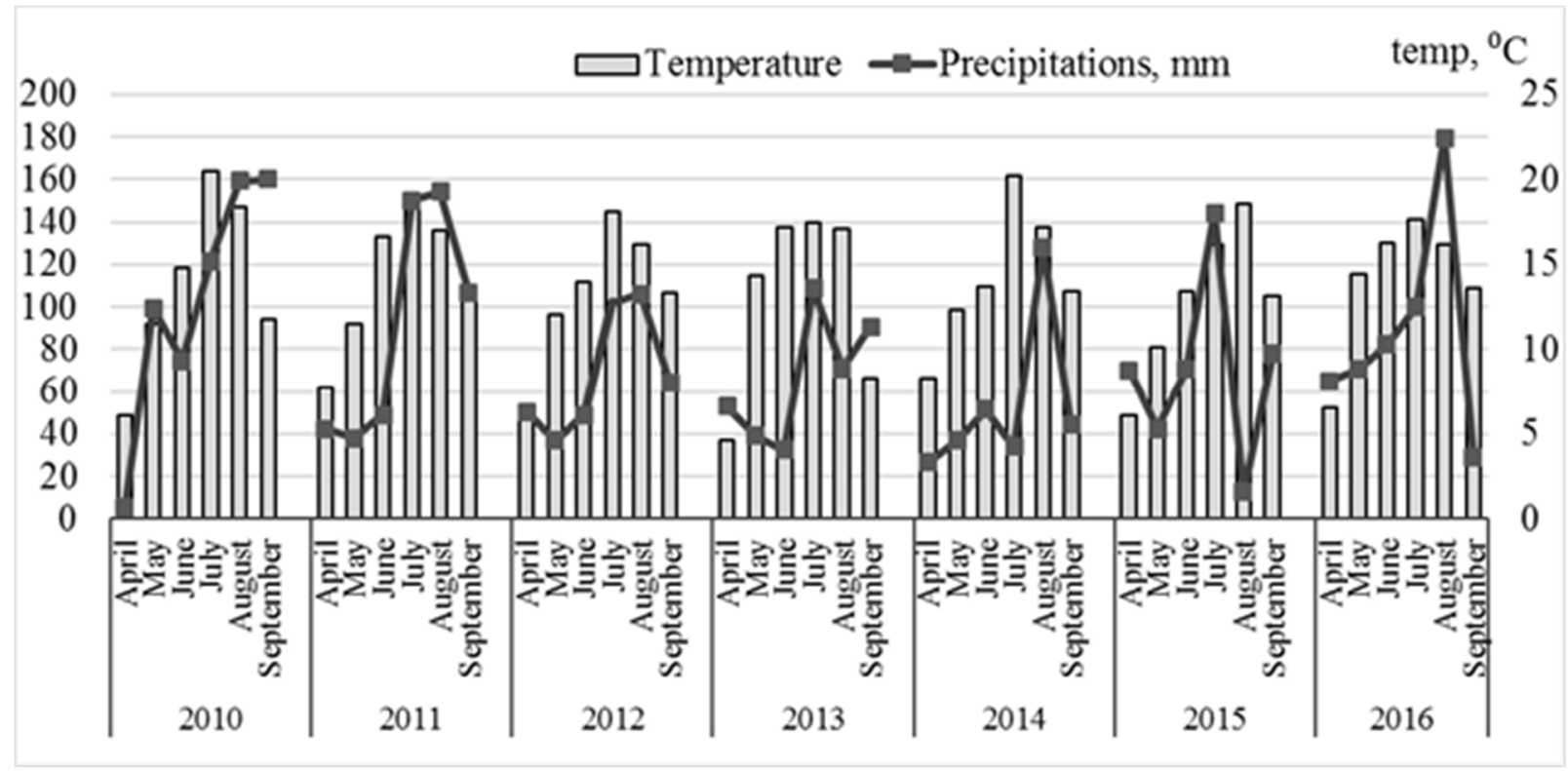

Figure 3. Meteorological parameters-the sum of precipitation (in $\mathrm{mm}, \mathrm{PCPN}$ ) and the average monthly temperature $\left({ }^{\circ} \mathrm{C}\right)$-for the vegetation months in 2010-2016.

Overall, the average monthly temperature and the precipitation were somewhat lower than in the two previous growing seasons. The growing season of 2014 might be characterized as the least favorable for grass growing, especially due to a cool and dry period in the first half of vegetation and a very warm and dry period up to mid-August. In 2015, relatively cool and rainy weather prevailed until mid-July. Later, there was a drought period. In 2016, the regimes of precipitation and temperature were very favorable for both the 1st and the 2nd (aftermath) biomass growing.

\subsection{Dry Matter (DM) Yield, LUE and NUE}

According to the data of Fisher's criterion mean squares, growing year $(Y)$, nitrogen rate $(N)$ and the interaction of both parameters $(Y \times N)$ had a significant positive effect on the dry matter (DM) of reed canary grass (1st and 2nd cuts) yields $(p<0.01)$. Similarly, nitrogen utilization efficiency (NUE) was positively influenced by growing year, nitrogen rate and their interaction $(p<0.01)$. Only once, liming rate $(L)$ had a statistically positive impact on 1st cut DM yield (at $95 \%$ probability level). Further, liming rate, the interaction of growing year $\times$ liming rate $(Y \times L)$, liming rate $\times$ nitrogen rate $(L \times N)$ and the interaction of three variables: growing year $\times$ liming rate $\times$ nitrogen rate $(Y \times L \times N)$ had no impact on any parameters studied (Table 1 ). 
Table 1. Fisher criterion's mean squares for the dry matter (DM) of reed canary grass yields, lime and nitrogen efficiency (LUE, NUE) during the 2010-2016 growing seasons.

\begin{tabular}{ccccccc}
\hline \multirow{2}{*}{ Variables } & \multicolumn{3}{c}{ DM (kg ha $\mathbf{~}^{\mathbf{1}}$ ) } & NUE & LUE \\
\cline { 2 - 4 } & 1st cut & 2nd cut & Total & & \\
\hline$Y$ & $* *$ & $* *$ & $* *$ & $* *$ & $n s$ \\
$L$ & $*$ & $n s$ & $n s$ & $n s$ & $n s$ \\
$N$ & $* *$ & $* *$ & $n s$ & $* *$ & $n s$ & $n s$ \\
$Y \times L$ & $n s$ & $* *$ & $* *$ & $* *$ & $n s$ \\
$Y \times N$ & $* *$ & $n s$ & $n s$ & $n s$ & $n s$ \\
$L \times N$ & $n s$ & $n s$ & $n s$ & $n s$ & $n s$ \\
$Y \times L \times N$ & $n s$ & $n s$ &
\end{tabular}

Note: DM—dry matter; NUE—nitrogen utilization efficiency; LUE—liming utilization efficiency. *—significant at $p<0.05 ;{ }^{* *}$ - significant at $p<0.01 ; n s$ - not significant.

Table 2 shows the results of dry matter (DM) yield of reed canary grass, nitrogen utilization efficiency (NUE) and liming utilization efficiency (LUE). As it was stated, DM yield of reed canary grass was measured twice per vegetation: at full maturity (the end of June) and the aftermath (at the end of September). The average annual DM yield (including 1st and 2nd cuttings) over 7 consecutive years was $7184 \mathrm{~kg} \mathrm{ha}^{-1}$ (DM yield ranged from $5442 \mathrm{~kg} \mathrm{ha}^{-1}$ in 2015 to $11,115 \mathrm{~kg} \mathrm{ha}^{-1}$ in 2011).

Table 2. The average values of DM yield of reed canary grass, nitrogen utilization efficiency (NUE) and liming utilization efficiency (LUE) as affected by cultivation year, liming and nitrogen application.

\begin{tabular}{|c|c|c|c|c|c|}
\hline \multirow{2}{*}{ Variables } & \multicolumn{3}{|c|}{ Dry Matter Yield (DM) (kg ha $\left.{ }^{-1}\right)$} & \multirow{2}{*}{$\begin{array}{c}\text { NUE } \\
\left(\mathrm{kg} \mathrm{kg}^{-1}\right)\end{array}$} & \multirow{2}{*}{$\begin{array}{c}\text { LUE } \\
\left(\mathrm{t} \mathrm{kg}^{-1}\right)\end{array}$} \\
\hline & 1st Cut Yield & 2nd Cut Yield & Total & & \\
\hline \multicolumn{6}{|c|}{ Cultivation Year } \\
\hline 2010 & 4116 & 4330 & 8445 & 38.24 & -54.16 \\
\hline 2011 & 7432 & 3401 & 11,115 & 59.64 & 181.75 \\
\hline 2012 & 4095 & 2410 & 6505 & 54.39 & -16.02 \\
\hline 2013 & 4006 & 1696 & 5777 & 55.69 & -79.81 \\
\hline 2014 & 3737 & 1731 & 5468 & 34.25 & 92.87 \\
\hline 2015 & 5040 & 738 & 5443 & 40.49 & 177.31 \\
\hline 2016 & 5198 & 2619 & 7535 & 40.88 & 254.81 \\
\hline On average & 4803 & 2418 & 7184 & 46.22 & 79.53 \\
\hline $\mathrm{LSD}_{05 / 01}$ & $325 / 431$ & $226 / 299$ & $465 / 644$ & $8.39 / 11.1$ & $205 / 272$ \\
\hline \multicolumn{6}{|c|}{ Liming $\mathrm{CaCO}_{3}\left(\mathrm{tha}^{-1}\right)$} \\
\hline Not limed & 4547 & 2332 & 6434 & 43.41 & \\
\hline $3.0 \mathrm{tha}^{-1}$ & 4936 & 2341 & 6604 & 42.73 & -6.16 \\
\hline $6.0 \mathrm{tha}^{-1}$ & 4928 & 2379 & 6897 & 43.68 & 77.17 \\
\hline $\mathrm{LSD}_{05 / 01}$ & $188 / 249$ & $130 / 173$ & $232 / 372$ & $3.97 / 6.42$ & $83.9 / 111$ \\
\hline \multicolumn{6}{|c|}{ Nitrogen application $\left(\mathrm{kg} \mathrm{ha}^{-1}\right)$} \\
\hline $0 \mathrm{~kg} \mathrm{ha}^{-1}$ & 2932 & 1315 & 4015 & & 77.16 \\
\hline $60 \mathrm{~kg} \mathrm{ha}^{-1}$ & 4794 & 1523 & 6054 & 34.77 & -14.29 \\
\hline $120 \mathrm{~kg} \mathrm{ha}^{-1}$ & 6684 & 4415 & 9866 & 51.78 & 43.65 \\
\hline $\mathrm{LSD}_{05 / 01}$ & $188 / 249$ & $130 / 173$ & $232 / 372$ & $2.81 / 4.54$ & $118.7 / 157$ \\
\hline
\end{tabular}

In the first growing seasons of 2010 and 2011, reed canary grass produced a high DM yield for both the 1st and 2nd grass cuttings-8445 and 11,115 $\mathrm{kg} \mathrm{ha}^{-1}$, respectively. This high DM yield was influenced by a particularly favorable moisture regime (especially during the periods of intensive grass growth). Significantly lower DM yields (both for 1st and 2nd cuts) were recorded over the next three years (at 99\% probability level). In 2012 and 2013, despite the precipitation and daily temperatures being close to the long-term average, there were several growing periods with a lack of moisture in the topsoil, resulting in reduced grass productivity. The least productive was the growing season of 2014. Low yields of the 1st cut were largely related to low rainfall and low average daily temperatures. 
The abundance of rain at the end of vegetation had only a minor impact on the 2nd cut DM yields. Again, 1st cut DM yield increased significantly over the next two seasons; the moisture content was sufficient to produce high DM yields of reed canary grass.

Depending on the growing year, the share of DM yield of the 1st cut was the lowest in 2010-48.7\%; meanwhile in 2015, DM yield increased to $92.6 \%$. In other experimental years, the share of the 1st cut grass was roughly similar (62.9-69.3\%). In the first two experimental years, the average 2nd grass yield (aftermath) was quite high and amounted to 4330 and $3401 \mathrm{~kg} \mathrm{ha}^{-1}$, respectively. Over the next four years (from 2012 to 2015) due to lower moisture availability in the second half of the growing season, the 2nd cut grass DM significantly decreased. The lowest average 2nd grass yield (aftermath) was in 2015-738 $\mathrm{kg} \mathrm{ha}^{-1}$.

The total DM yield of reed canary grass strongly correlated with the number of precipitations $(+0.79)$ and to lesser extent with the average daily temperature during the vegetation months $(+0.55)$.

Naturally, reed canary grass is grown in wet soils predominantly $[35,36]$. In this respect, the water regime during the vegetation period is a crucial factor for reed canary grass productivity.

The presented results indicate that the use of $3.0 \mathrm{tha}^{-1} \mathrm{CaCO}_{3}$ rate had a positive effect on 1st cut DM yield. However, no other positive effect of liming on the total DM yield was estimated. Thus, for the cultivation of reed canary grass soil liming is inexpedient and the species could be successfully grown under the conditions of naturally acidic light loam Retisol.

Nitrogen was the key factor influencing the productivity of reed canary grass. Based on 7-year average data, the use of N60 and N120 rates improved the average annual DM yield by 2039 and $5851 \mathrm{~kg} \mathrm{ha}^{-1}$ (or by 51 and 146\%), respectively (at 99\% probability level).

The results of our experiment are consistent with other research data that reed canary grass requires water and nitrogen in the soil in order to produce high biomass yields $[24,37]$. The study revealed that the use of N120 rate is optimal for maximizing the productivity of reed canary grass. Previous studies carried out in Vèžaičiai Branch revealed that, by using double $\mathrm{N}$ rate (N240), the average annual DM yield of reed canary grass was quite similar in comparison with the results of our experiment-from 10,600 to $12,300 \mathrm{~kg} \mathrm{ha}^{-1}$ [38]. Tilvikienè et al. also revealed that the use of 90 and $180 \mathrm{~kg} \mathrm{ha}^{-1} \mathrm{~N}$ rates had a similar impact on DM yield [12].

Only when growing in low-productivity sandy soil, when the $\mathrm{N}$ rate increased from 50 to $250 \mathrm{~kg} \mathrm{ha}^{-1}$, the average annual yield of reed canary grass increased from 2.93 to $3.90 \mathrm{t} \mathrm{ha}^{-1}$ [23]. Overall, the use of such a high rate of $\mathrm{N}$ fertilization is uneconomical and does not meet environmental requirements [39,40].

Nitrogen utilization efficiency (NUE) varied greatly depending on the growing year. As we can observe from the Table, the highest average NUE values were recorded in $2011-59.64$ (or $1 \mathrm{~kg}$ of $\mathrm{N}$ increased the DM yield of reed canary grass by $59.64 \mathrm{~kg}$ ) (in the second harvest year). NUE values remained high for three consecutive growing seasons. Since then, nitrogen efficiency values have declined, and their average values over the next three years ranged from 34.25 (in 2014) to 40.88 (in 2016). Thus, the data show that the efficiency of nitrogen fertilizers for reed canary grass becomes significantly lower after several years of growth.

Soil liming (or growing at different soil $\mathrm{pH}$ levels) had no impact on nitrogen application efficiency. Annual nitrogen application had a significant effect on NUE values. At N60 and N120 nitrogen rates, the average NUE values were 34.77 and 51.78, respectively. NUE values had a strong and positive correlation with the total DM yield (+0.74).

Liming utilization efficiency (LUE) values varied greatly depending on the year of growth. However, it can be observed that in many cases the efficiency of liming was not statistically reliable. There was a tendency for LUE values to be slightly higher in 2015 and 2016 (although not statistically reliable at the $95 \%$ probability level). In other words, the use of liming (or liming rate) had no significant effect on LUE values. 
Biomass chemical content. The chemical content of reed canary grass biomass is presented in Table 3. Based on the 3-year average data and irrespective of the cutting time, $\mathrm{C}_{\text {org }}$ organic content was essentially similar. With the exception of organic carbon $\left(\mathrm{C}_{\mathrm{org}}\right)$ content in biomass, other chemical parameters of reed grass biomass - total $\mathrm{N}\left(\mathrm{N}_{\text {tot }}\right), \mathrm{C}: \mathrm{N}$ ratio, crude fiber $\left(\mathrm{C}_{\mathrm{fib}}\right)$, crude ash $\left(\mathrm{C}_{\mathrm{ash}}\right)$, calorific value $(\mathrm{CV})$ and $\mathrm{C}: \mathrm{N}$ ratio-varied depending on the harvesting (1st or 2nd cuts) time (Table 3). Higher crude fiber content and higher calorific value were recorded at the 1st cut; meanwhile, total $\mathrm{N}$ and crude fat content was higher in the aftermath.

Table 3. Crude protein, crude fiber, crude fat, crude ash $\left(\mathrm{mg} \mathrm{kg}^{-1}\right)$, calorific value $\left(\mathrm{MJ} \mathrm{kg}^{-1}\right)$ and nitrogen nutrition index in reed canary grass biomass at full maturity stage and the aftermath in 2010-2012.

\begin{tabular}{|c|c|c|c|c|c|c|c|c|}
\hline Variables & $\mathrm{C}_{\text {org }}$ & $\mathbf{N}_{\text {tot }}$ & C:N Ratio & $\mathrm{C}_{\mathrm{fib}}$ & $\mathrm{C}_{\text {fat }}$ & $\mathrm{C}_{\mathrm{ash}}$ & $\mathrm{CV}$ & NNI \\
\hline \multicolumn{9}{|c|}{ 1st cut (full maturity stage) } \\
\hline 2010 & 45.27 & 1.11 & 41.62 & 37.11 & 0.83 & 5.92 & 17.89 & 0.92 \\
\hline 2011 & 45.76 & 1.12 & 41.84 & 38.78 & 0.85 & 5.08 & 18.00 & $1.15^{* *}$ \\
\hline 2012 & $56.93^{* *}$ & $0.67 * *$ & $87.32^{* *}$ & 38.79 & 1.42 & 4.59 & 18.05 & $0.53^{* *}$ \\
\hline $\begin{array}{c}\mathrm{LSD}_{05 /} \\
01\end{array}$ & $\begin{array}{c}0.69 / \\
0.93\end{array}$ & $\begin{array}{c}0.06 / \\
0.07\end{array}$ & $\begin{array}{c}3.25 / \\
4.36\end{array}$ & $\begin{array}{l}0.87 / \\
1.17\end{array}$ & $\begin{array}{c}0.13 / \\
0.18\end{array}$ & $\begin{array}{c}0.16 / \\
0.22\end{array}$ & $\begin{array}{c}0.03 / \\
0.04\end{array}$ & $\begin{array}{c}0.05 / \\
0.07\end{array}$ \\
\hline \multicolumn{9}{|c|}{ Liming $\mathrm{t} \mathrm{ha}^{-1}$} \\
\hline Not limed & 49.13 & 0.99 & 54.56 & 37.91 & 1.14 & 5.23 & 18.00 & 0.85 \\
\hline $3.0 \mathrm{tha}^{-1}$ & 49.57 & 0.95 & 57.59 & 37.93 & $0.96 *$ & 5.23 & $17.94 *$ & 0.87 \\
\hline $6.0 \mathrm{tha}^{-1}$ & 49.26 & 0.96 & $58.63 *$ & 38.85 & 1.01 & 5.14 & 17.99 & 0.88 \\
\hline $\mathrm{LSD}_{05 /}$ & $0.69 /$ & $0.05 /$ & $3.25 /$ & $0.87 /$ & $0.13 /$ & $0.16 /$ & $0.03 /$ & $0.05 /$ \\
\hline 01 & 0.93 & 0.07 & 4.36 & 1.17 & 0.18 & 0.22 & 0.04 & 0.07 \\
\hline \multicolumn{9}{|c|}{ Nitrogen application, $\mathrm{kg} \mathrm{ha}^{-1}$} \\
\hline $0 \mathrm{~kg} \mathrm{ha}^{-1}$ & 49.26 & 0.90 & 60.90 & 37.41 & 1.07 & 5.43 & 17.91 & 0.69 \\
\hline $\begin{array}{c}120 \mathrm{~kg} \\
\mathrm{ha}^{-1}\end{array}$ & 49.39 & $1.03 * *$ & $52.95^{* *}$ & $39.05^{* *}$ & 1.00 & $4.96^{* *}$ & $18.02 * *$ & $1.05^{* *}$ \\
\hline $\begin{array}{c}\mathrm{LSD}_{05 /} \\
01\end{array}$ & $\begin{array}{c}0.49 / \\
0.66\end{array}$ & $\begin{array}{l}0.04 / \\
0.05\end{array}$ & $\begin{array}{l}2.30 / \\
3.08\end{array}$ & $\begin{array}{l}0.62 / \\
0.83\end{array}$ & $\begin{array}{l}0.10 / \\
0.13\end{array}$ & $\begin{array}{l}0.12 / \\
0.16\end{array}$ & $\begin{array}{l}0.02 / \\
0.03\end{array}$ & $\begin{array}{l}0.04 / \\
0.05\end{array}$ \\
\hline \multicolumn{9}{|c|}{ 2nd cut (aftermath) } \\
\hline 2010 & 44.98 & 1.78 & 25.88 & 30.49 & 1.78 & 8.12 & 17.51 & 1.53 \\
\hline 2011 & 44.7 & $1.37^{* *}$ & 32.87 & 35.34 & $0.59^{* *}$ & $7.72^{* *}$ & 17.53 & $1.05^{* *}$ \\
\hline 2012 & $56.26^{* *}$ & $1.27^{* *}$ & $48.11^{* *}$ & $30.26^{* *}$ & $0.92 * *$ & $6.38^{* *}$ & 17.59 & $0.81^{* *}$ \\
\hline $\mathrm{LSD}_{05 /}$ & $0.52 /$ & $0.11 /$ & $3.25 /$ & $0.58 /$ & $0.13 /$ & $0.24 /$ & $0.06 /$ & $0.12 /$ \\
\hline 01 & 0.69 & 0.15 & 4.37 & 0.78 & 0.18 & 0.32 & 0.08 & 0.16 \\
\hline \multicolumn{9}{|c|}{ Liming $\mathrm{t} \mathrm{ha}^{-1}$} \\
\hline Not limed & 48.29 & 1.44 & 33.78 & 31.78 & 1.18 & 7.51 & 17.50 & 1.14 \\
\hline $3.0 \mathrm{tha}^{-1}$ & 48.66 & 1.47 & 36.38 & 32.07 & 1.15 & 7.35 & 17.50 & 1.11 \\
\hline $6.0 \mathrm{tha}^{-1}$ & 48.79 & $1.52 *$ & 36.70 & 32.23 & $0.97^{*}$ & 7.35 & 17.53 & 1.14 \\
\hline $\mathrm{LSD}_{05 /}$ & $0.52 /$ & $0.11 /$ & $3.25 /$ & $0.58 /$ & $0.13 /$ & $0.24 /$ & $0.06 /$ & $0.12 /$ \\
\hline 01 & 0.69 & 0.15 & 4.37 & 0.78 & 0.18 & 0.32 & 0.08 & 0.16 \\
\hline \multicolumn{9}{|c|}{ Nitrogen application, $\mathrm{kg} \mathrm{ha}^{-1}$} \\
\hline $0 \mathrm{~kg} \mathrm{ha}^{-1}$ & 48.12 & 1.40 & 37.35 & 31.37 & 1.32 & 8.45 & 17.38 & 0.88 \\
\hline $\begin{array}{c}120 \mathrm{~kg} \\
\mathrm{ha}^{-1}\end{array}$ & $49.17^{* *}$ & $1.55^{* *}$ & $33.89^{* *}$ & $32.69^{* *}$ & $0.88^{* *}$ & $6.36^{* *}$ & $17.64^{* *}$ & $1.38^{* *}$ \\
\hline $\mathrm{LSD}_{05 /}$ & $0.36 /$ & $0.10 /$ & $2.30 /$ & $0.41 /$ & $0.09 /$ & $0.17 /$ & $0.04 /$ & $0.08 /$ \\
\hline 01 & 0.49 & 0.13 & 3.09 & 0.56 & 0.13 & 0.22 & 0.06 & 0.11 \\
\hline
\end{tabular}

*-significant at $95 \%$ probability level; **_significant at $99 \%$ probability level.

Soil liming (or growth at different soil $\mathrm{pH}$ levels) in many cases had insignificant effect on the parameters studied. In some cases, statistically significant effect was found; however, such reliability was rather random as it did not reveal a clear trend.

$$
\begin{gathered}
\left.\mathrm{y}(\mathrm{CV})=6.90+0.02\left(\mathrm{C}_{\text {ash }}\right)+0.04\left(\mathrm{C}_{\text {fib }}\right)+0.20\left(\mathrm{C}_{\mathrm{org}}\right)+0.25\left(\mathrm{~N}_{\text {tot }}\right)-0.06\left(\mathrm{C}_{\text {fat }}\right) \text { (for 1st cut }\right) ; \\
\mathrm{R}=0.88 ; \mathrm{R} 2=0.77, \text { or }(\%)-77.0431 ; \mathrm{F} \text { act. }=4.03
\end{gathered}
$$




$$
\begin{gathered}
\mathrm{y}(\mathrm{CV})=14.24-0.11\left(\mathrm{C}_{\text {ash }}\right)+0.02\left(\mathrm{C}_{\text {fib }}\right)+0.08\left(\mathrm{C}_{\text {org }}\right)-0.06\left(\mathrm{~N}_{\text {tot }}\right)+0.04\left(\mathrm{C}_{\mathrm{fat}}\right)(\text { for } 2 \text { nd cut }) \\
\mathrm{R}=0.96 ; \mathrm{R} 2=0.92 \text { or }(\%)-91.76 ; \mathrm{F} \text { act. }=13.36^{* *}
\end{gathered}
$$

\subsection{Correlation between Biomass Yield and Nitrogen Nutrition Index}

The dependence of DM yield of reed canary grass and nitrogen nutrition index (NNI) might be expressed by the following exponential equations: $y=1563.53 \times \mathrm{e}^{1.22044 \mathrm{x}}$ (mutual correlation- +0.86 ); (for 1st cut) and $\mathrm{y}=0.59 \times \mathrm{e}^{0.0002 x}$ (for 2 nd cut) $(+0.85)$. These dependences are presented in Figures 4 and 5.

NNI

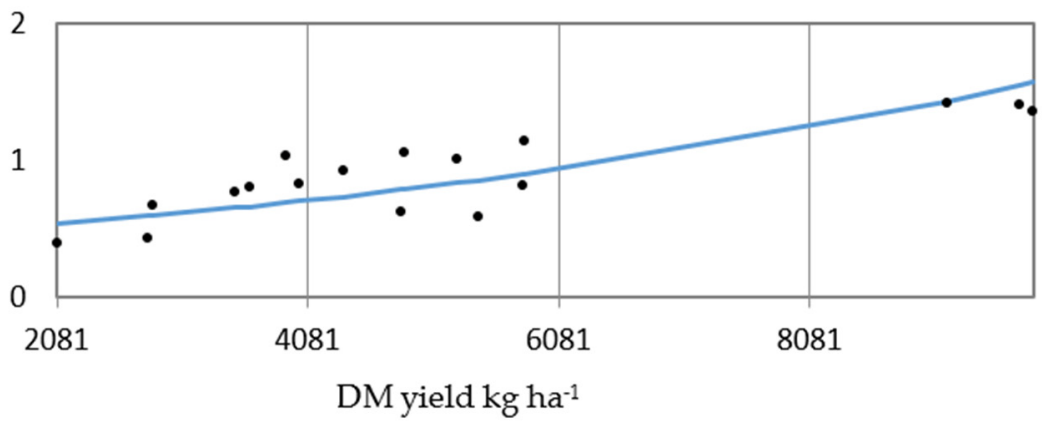

Figure 4. The mutual relationship between nitrogen nutrion index (NNI) and DM yield (1st cutting, 2010-2012).

NNI

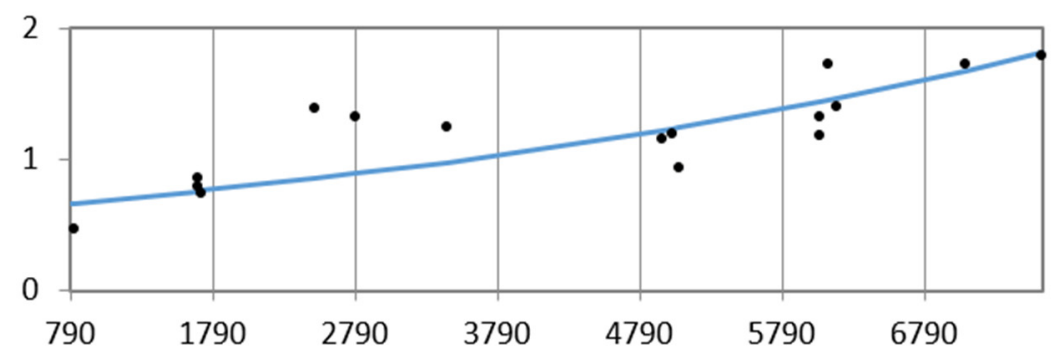

DM yield $\mathrm{kg} \mathrm{ha-1}$

Figure 5. The relationship between nitrogen nutrition index (NNI) and DM yield (2nd cutting, 2010-2012).

It can be observed that in comparison with the aftermath grass, NNI values for 1st cut grass dry matter are generally lower, below 1 . Despite the relatively high application rate of nitrogen each year, sufficient uptake of nitrogen as a vital nutrient for growing plants might be restricted by unfavorable growing conditions (particularly soil moisture regime).

In addition, the decrease of NNI might be determined by the fact that for several years in a row, a part of the reed canary grass sward was growing in the area not fertilized with nitrogen (control treatment); thus, it may accelerate the lack of available nitrogen in the soil as well in aboveground biomass.

\subsection{Recycling of Plants to Biofuel and Utilization for Energy Purposes}

Biometric and qualitative parameters of biofuel pellets. After proper preparation of reed canary grass and wood sawdust biomass as well as production of biofuel pellets, they were measured (length and diameter) and weighed. Volumes and densities with their square errors were then calculated. The results obtained are presented in Table 4. 
Table 4. Biometric and qualitative parameters of the pellets.

\begin{tabular}{|c|c|c|c|c|c|c|}
\hline \multirow[b]{2}{*}{ Plant Species } & \multicolumn{6}{|c|}{ Parameters of Pellets } \\
\hline & $\begin{array}{c}\text { Moisture } \\
\text { content, \% }\end{array}$ & Length, mm & Diameter, mm & Mass, $\mathrm{g}$ & Volume, $\mathrm{m}^{3}$ & Density, $\mathrm{kg} \mathrm{m}^{-3}$ \\
\hline $\begin{array}{c}\text { Reed canary } \\
\text { grass }\end{array}$ & 6.7 & $23.62 \pm 0.92$ & $6.11 \pm 0.10$ & $0.85 \pm 0.05$ & $7.36 \pm 0.42 \times 10^{-7}$ & $\begin{array}{c}1154.8 \pm 94.5 \\
1077.4 \pm 88.1 \\
(\mathrm{DM})\end{array}$ \\
\hline Wood sawdust & 7.6 & $30.61 \pm 2.51$ & $6.09 \pm 0.12$ & $1.06 \pm 0.06$ & $8.90 \pm 0.59 \times 10^{-7}$ & $\begin{array}{c}1194.2 \pm 50.0 \\
1103.4 \pm 46.2 \\
(\mathrm{DM})\end{array}$ \\
\hline
\end{tabular}

After analyzing the biometric properties and the density of the reed canary grass produced and the control sample-wood sawdust granules-by measuring and weighting them, it was determined that the granules pressed with a horizontal matrix were of very high quality. Very important indicators, such as the density of the granules, were high enough and it exceeded $1000 \mathrm{~kg} \mathrm{~m}^{-3} \mathrm{DM}$ (dry matter).

Analysis of the data presented in Table 4 shows that the density of reed canary grass was $1154.8 \pm 94.5 \mathrm{~kg} \mathrm{~m}^{-3}$, and it was only slightly lower than the density of traditionally used wood sawdust pellets-1194.2 $\pm 50.0 \mathrm{~kg} \mathrm{~m}^{-3}\left(1077.4 \pm 88.1 \mathrm{~kg} \mathrm{~m}^{-3} \mathrm{DM}\right.$ and $1103.4 \pm 462 \mathrm{~kg} \mathrm{~m}^{-3} \mathrm{DM}$, respectively). Based on these research results, it can be stated that the determined pellet densities of the investigated plants differ slightly and they satisfy the requirements for transportation, storage and burning of granulated solid biofuel.

Moisture content is an important factor determining the net energy content of a biomass material, as it affects the calorific value, burning efficiency and burning temperature of biofuels [32]. The results of the investigated moisture of reed canary grass and wood sawdust pellets showed that the determined pellet moisture content ranged from $6.7 \%$ to $7.6 \%$. Such a moisture content is suitable for biofuel pellets.

Determination of harmful emissions. Harmful emissions of carbon dioxide $\mathrm{CO}_{2}$, carbon monoxide $\mathrm{CO}$, nitrogen oxides NOx and unburned hydrocarbons $\mathrm{C}_{\mathrm{x}} \mathrm{H}_{\mathrm{y}}$ were estimated by burning reed canary grass and wood sawdust pellets in the laboratory of the Lithuanian Energy Institute. The limit values of emitted pollutants from fuel-burning devices in Lithuania are regulated by the norms of emitted pollutants from fuel-burning devices (LAND 43-2013) [41].

The determined emissions of harmful pollutants obtained by burning granules are presented in Table 5, and the dynamics of the emission of harmful gases from burning reed canary grass is presented in Figure 6. The research results show that the combustion process is slowed down when the loaded portion of plant pellets is finishing to burn or when the burning intensity decreases. Emissions of all harmful combustion gases also tend to decrease.

Low carbon dioxide $\left(\mathrm{CO}_{2}\right)$ emissions were recorded when burning reed canary grass and wood sawdust pellets. These emissions varied from 7.4 to $5.2 \%$, respectively. However, other emissions from burning reed canary grass pellets were several times higher than from burning wood sawdust biofuels: carbon monoxide (CO) concentrations reached $905.2 \mathrm{ppm}$, nitrogen oxides (NOx) - $176.2 \mathrm{ppm}$ and unburned hydrocarbons (CxHy) $56.2 \mathrm{ppm}$. Summarizing the results of the aforementioned emissions, it can be stated that during the combustion of reed canary grass pellets, all harmful emissions did not exceed the permissible values. Thus, assessing the results of harmful gas emissions, it can be stated that these pellets maybe recommended for burning in domestic boilers.

Table 5. Harmful emissions by burning plant pellets (averages).

\begin{tabular}{ccccc}
\hline Plant Species & $\mathbf{C O}_{\mathbf{2}} \%$ & $\mathbf{C O} \mathbf{p p m}$ & $\mathbf{N O}_{\mathbf{x}} \mathbf{p p m}$ & $\mathbf{C}_{\mathbf{x}} \mathbf{H}_{\mathbf{y}} \mathbf{p p m}$ \\
\hline Reed canary grass & 7.4 & 905.2 & 176.2 & 56.2 \\
Wood sawdust & 5.2 & 92.0 & 51.1 & 12.0 \\
\hline
\end{tabular}


$\mathrm{CO}_{2}, \%$

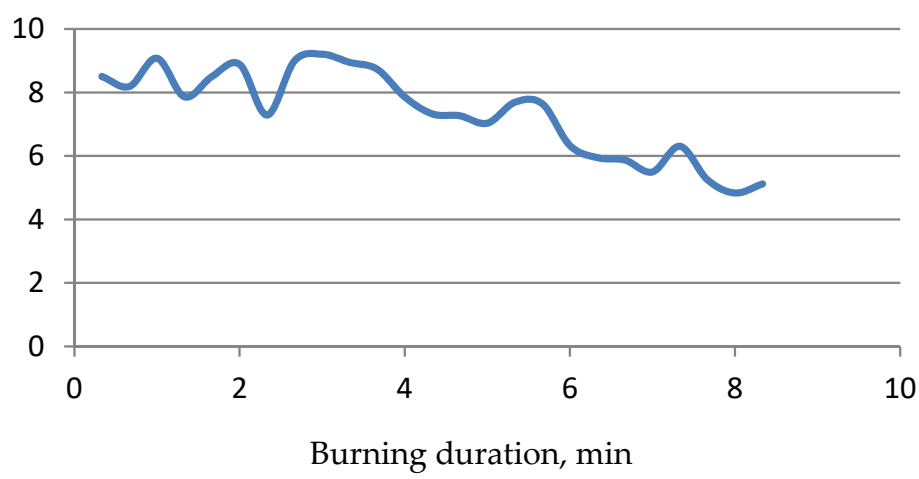

(a)

CO, ppm

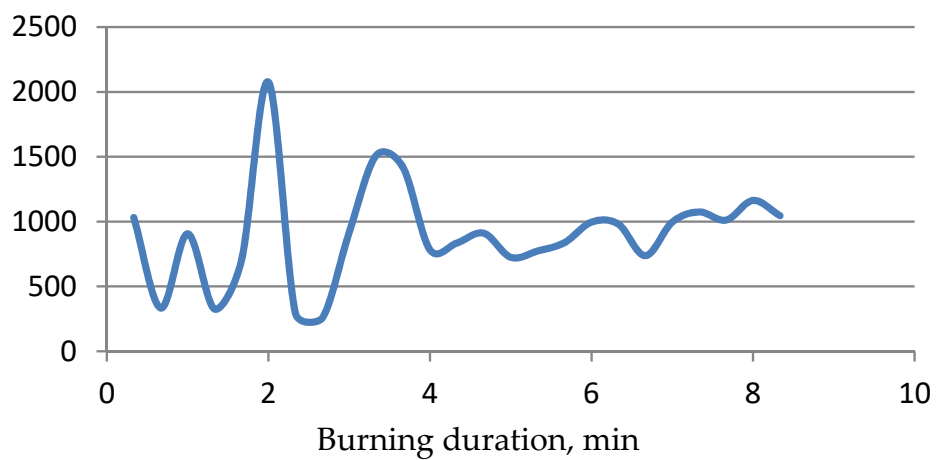

(b)

NOx, ppm

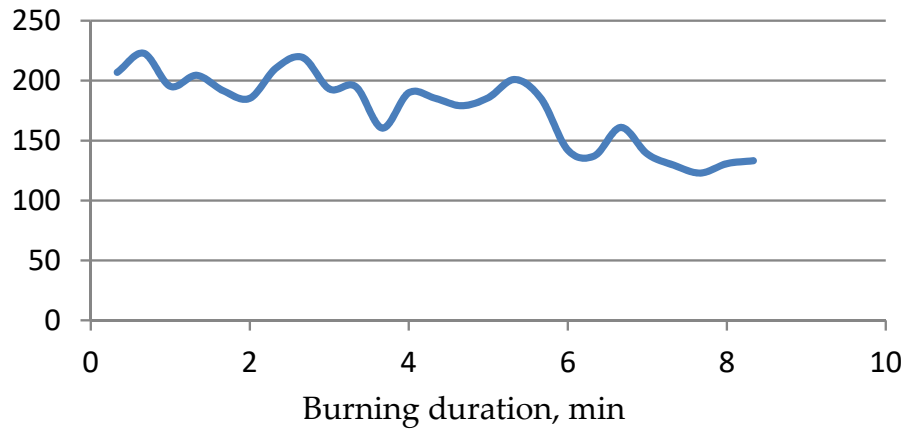

(c)

CxHy, ppm

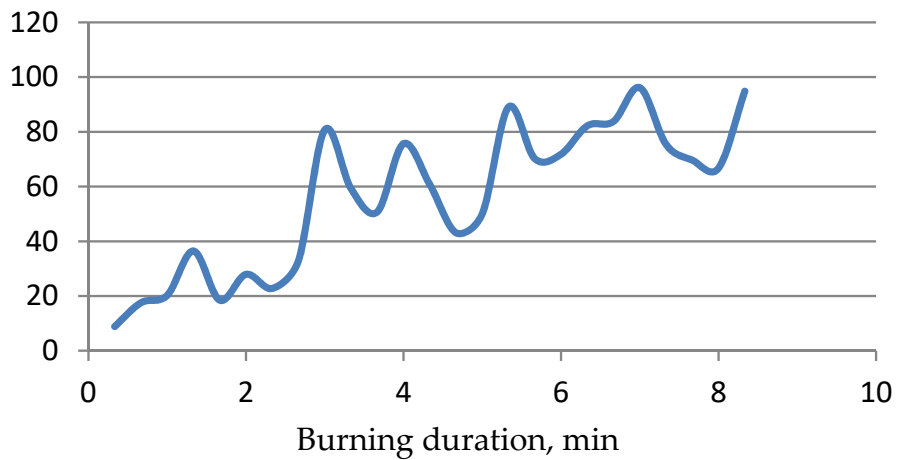

(d)

Figure 6. The dynamics of harmful emissions from burning the reed canary grass: (a) — carbon dioxide; (b)—carbon monoxide; (c)—nitrogen oxides; (d)—unburned hydrocarbons. 


\section{Conclusions}

Before establishing the experiment in Western Lithuanian Retisol, we set a goal of investigating the possibility to grow reed canary grass (Phalaris arundinacea L.) at different soil acidity levels. Based on experimental data, we can state that the species could be successfully cultivated for 7 and more years without reseeding under highly acidic soil conditions. According to our experimental data, the total DM yield varied between the growing seasons by $104 \%$.

According to our experimental data, the use of lime material had only a minor effect on the productivity of reed canary grass and the efficiency of $\mathrm{N}$ fertilization. In this respect, liming is economically inefficient, not only for reed canary grass but for other perennial energy grasses as well. However, liming significantly improved soil quality (results on the effect of liming on soil chemical content at the reed canary grass growing site will be published in a separate article).

Nitrogen was an essential factor influencing the productivity of reed canary grass. The study revealed that the use of N120 rate (by using split doses: N60 before the beginning of vegetation and N60 after the 1st grass cut) is optimal for maximizing the productivity of reed canary grass. The efficiency of nitrogen fertilization or nitrogen utilization efficiency (NUE) varied in dependence on the growing year (particularly precipitation regime).

We can notice that due to higher Cfib and lower Cash contents, calorific value (CV) was higher in the 1stcutting grass. In this respect 1st cutting grass is more suitable for solid biofuel production. The 2nd grass (aftermath) is more suitable for biogas production due to both the most unfavorable autumn weather conditions and the corresponding chemical composition (especially due to more favorable $\mathrm{C}: \mathrm{N}$ ratio and lower fiber content). The suitability of reed canary for biogas production at their individual growth stages will be described in later articles.

The possibilities of using reed canary grass for solid biofuels by pressing them into pellets were investigated. After analyzing the physical and biometric properties of the produced reed canary grass and the control sample-wood sawdust granules-it was found that the granules obtained have a sufficiently high density that exceeds $1000 \mathrm{kgm}^{-3}$ DM (dry matter). The determined emissions of harmful gases from the combustion of reed canary grass pellets were several times higher than when burning wood sawdust biofuels. Summarizing the results of the investigated emissions, it can be stated that during the combustion of reed canary grass pellets, all harmful emissions did not exceed the permissible values. Thus, assessing the results of the quality indicators of reed canary grass pellets and the emissions of harmful gases, it can be stated that these investigated pellets may be recommended for burning in domestic boilers with low and average capacity.

Author Contributions: Conceptualization: G.Š. and A.J.; methodology: G.Š., A.J. and R.S.; validation: G.Š., A.J. and R.R.; formal analysis: A.J. and E.Š.; investigation: G.Š., A.J. and R.S.; resources: G.Š. and A.J.; data curation: G.Š., A.J., D.K and R.R.; writing: G.Š., A.J., E.Š., R.R. and D.K.; writing-review and editing: G.Š., A.J., E.Š. and R.S.; visualization: G.Š., A.J., D.K. and R.R.; supervision, G.Š. and A.J. All authors have read and agreed to the published version of the manuscript.

Funding: This research received no external funding.

Institutional Review Board Statement: Not applicable.

Informed Consent Statement: Not applicable.

Data Availability Statement: Data sharing not applicable.

Acknowledgments: This study was conducted in compliance with the long-term program "Plant biopotential and quality for multifunctional practice".

Conflicts of Interest: The authors declare no conflict of interest. 


\section{References}

1. Lewandowski, I.; Scurlock, J.M.O.; Lindwall, E.; Christou, M. The development and current status of perennial rhizomatous grasses as energy crops in the US and Europe. Biomass Bioenergy 2003, 25, 335-361. [CrossRef]

2. Marks-Bielska, R.; Bielski, S.; Novikova, A.; Romaneckas, K. Straw Stocks as a Source of Renewable Energy. A Case Study of a District in Poland. Sustainability 2019, 11, 4714. [CrossRef]

3. Ymeri, P.; Gyuricza, C.; Fogarassy, C. Farmers' Attitudes towards the Use of Biomass as Renewable Energy—A Case Study from Southeastern Europe. Sustainability 2020, 12, 4009. [CrossRef]

4. Shurpali, N.J.; Hyvönen, N.P.; Huttunen, J.T.; Clement, R.J.; Reichstein, M.; Nykänen, H.; Biasi, C.; Martikainen, P.J. Cultivation of a perennial grass for bioenergy on a boreal organic soil-Carbon sinks or source? Glob. Change Biol. Bioenergy 2009, 1, 35-50. [CrossRef]

5. Mažvila, J.; Adomaitis, T.; Eitmanavičius, L. Changes in the acidity of Lithuania's soils as affected of not liming. Zemdirbyste 2004, 88, 3-20. (In Lithuanian)

6. Blanco-Canqui, H. Growing Dedicated Energy Crops on Marginal Lands and Ecosystem Services. Soil Sci. Soc. Am. J. 2016, 4, 845-858. [CrossRef]

7. Fernando, A.L.; Duarte, M.P.; Almeida, J.; Boléo, S.; Mendes, B. Environmental impact assessment of energy crops cultivation in Europe. Biofuel. Bioprod. Biorefin. 2010, 4, 594-604. [CrossRef]

8. Rahimi, V.; Shafiei, M. Techno-economic assessment of a biorefinery based on low-impact energy crops: A step towards commercial production of biodiesel, biogas, and heat. Energy Convers. Manag. 2019, 183, 698-707. [CrossRef]

9. Sherringtona, C.; Bartleyb, J.; Morana, D. Farm-level constraints on the domestic supply of perennial energy crops in the UK. Energy Policy 2008, 36, 2504-2512. [CrossRef]

10. Carlsson, G.; Martensson, L.-M.; Prade, T.; Svensson, S.-E.; Jensen, E.S. Perennial species mixtures for multifunctional production of biomass on marginal land. Glob. Change Biol. Bioenergy 2017, 9, 191-201. [CrossRef]

11. Scordia, D.; Cosentino, S.L. Perennial Energy Grasses: Resilient Crops in a Changing European Agriculture. Agriculture 2019, 9, 169. [CrossRef]

12. Tilvikienè, V.; Venslauskas, K.; Navickas, K.; Župerka, V.; Dabkevičius, Z.; Kadžiulienè, Ž. The biomass and biogas productivity of perennial grasses. Zemdirbyste 2012, 99, 17-22.

13. Christian, D.G.; Yates, N.E.; Riche, A.B. The effect of harvest date on the yield and mineral content of Phalaris arundinacea L. (reed canary grass) genotypes screened for their potential as energy crops in southern England. J. Sci. Food Agric. 2006, 86, 1181-1188. [CrossRef]

14. Hadders, G.; Olsson, R. Harvest of grass for combustion in late summer and in spring. Biomass Bioenergy 1997, 12, 171-175. [CrossRef]

15. Lord, R.A. Reed canarygrass (Phalaris arundinacea) outperforms Miscanthus or willow on marginal soils, brownfield and nonagricultural sites for local, sustainable energy crop production. Biomass Bioenergy 2015, 78, 110-125. [CrossRef]

16. Ustak, S.; Šinko, J.; Muňoz, J. Reed canary grass (Phalaris arundinacea L.) as a promising energy crop. J. Cent. Eur. Agric. 2019, 20, 1143-1168. [CrossRef]

17. Wrobel, C.; Coulman, B.E.; Smith, D.L. The potential use of reed canarygrass (Phalaris arundinacea L.) as a biofuel crop. Acta Agric. Scand. B Soil Plant Sci. 2009, 59, 1-18.

18. Kukk, L.; Roostalu, H.; Suuster, E.; Rossner, H.; Shanskiy, M.; Astover, A. Reed canary grass biomass yield and energy use efficiency in Northern European pedoclimatic conditions. Biomass Bioenergy 2011, 35, 4407-4416. [CrossRef]

19. Levesque, M.P.; Mathur, S.P. Effect of liming on yield and nutrient concentration of reed canarygrass grown in two peat soils. Can. J. Soil Sci. 1983, 63, 469-478. [CrossRef]

20. Ridley, A.M.; Windsor, S.M. Persistence and tolerance to soil acidity of phalaris and cocksfoot in north-eastern Victoria. Aust. J. Exp. Agric. 1992, 32, 1069-1075. [CrossRef]

21. Hayes, R.C.; Li, G.D.; Conyers, M.K.; Virgona, J.M.; Dear, B.S. Lime increases productivity and the capacity of lucerne (Medicago sativa L.) and phalaris (Phalaris aquatica L.) to utilise stored soil water on an acidic soil in south-eastern Australia. Plant Soil 2016, 400, 29-43. [CrossRef]

22. Pocienè, L.; Kadžiulienè, Ž. Biomass yield and fibre components in reed canary grass and tall fescue grown as feedstock for combustion. Zemdirbyste 2016, 103, 297-304. [CrossRef]

23. Shield, I.F.; Barraclough, T.J.P.; Riche, A.B.; Yates, N.E. The yield response of the energy crops switchgrass and reed canary grass to fertiliser applications when grown on a low productivity sandy soil. Biomass Bioenergy 2012, 42, 86-96. [CrossRef]

24. Strašil, Z.; Váňa, V.; Káš, M. The reed canary grass (Phalaris arundinacea L.) cultivated for energy utilization. Res. Agric. Eng. 2005, 51, 7-12. [CrossRef]

25. Bailey, J.S. Liming and nitrogen efficiency: Some effects of increased calcium supply and increased soil pH on nitrogen recovery by perennial ryegrass. Commun. Soil Sci. Plant Anal. 1995, 26, 1233-1246. [CrossRef]

26. Bednarek, W.; Reszka, R. Effect of liming and fertilization with various nitrogen forms on the content of some cations in spring barley. Acta Agrophys. 2008, 12, 29-38.

27. Iglinski, B.; Iglin, A.; Kujawski, W.; Buczkowski, M.; Cichosz, R. Bioenergy in Poland. Renew. Sustain. Energy Rev. 2011, 15, 2999-3007. [CrossRef] 
28. Kadžiulienė, Ž.; Jasinskas, A.; Zinkevičius, R.; Makarevičienè, V.; Šarūnaitė, L.; Tilvikienè, V.; Šlepetys, J. Miscanthus biomass quality composition and methods of feedstock preparation for conversion into synthetic diesel fuel. Zemdirbyste 2014, 101, 27-34. [CrossRef]

29. Jasinskas, A.; Streikus, D.; Šarauskis, E.; Palšauskas, M.; Venslauskas, K. Energy evaluation and greenhouse gas emissions of reed plant pelletizing and utilization as solid biofuel. Energies 2020, 13, 1516. [CrossRef]

30. British Standards Institution. CEN/TC 14774-1:2005. Solid Biofuels-Methods for the Determination of Moisture Content-Oven Dry Method_Part 1: Total Moisture_Reference Method; British Standards Institution: London, UK, 2005.

31. Vares, V.; Kask, U.; Muiste, P.; Pihu, T.; Soosaar, S. Manual for Biofuel Users; Tallinn University of Technology: Tallinn, Estonia, 2005; p. 178.

32. Jasinskas, A.; Streikus, D.; Vonžodas, T. Fibrous hemp (Felina 32, USO 31, Finola) and fibrous nettle processing and usage of pressed biofuel for energy purposes. Renew. Energy 2020, 149, 11-21. [CrossRef]

33. Justes, E.; Mary, B.; Meynard, J.M.; Machet, J.M.; Thelier-Huché, L. Determination of a critical nitrogen dilution curve for winter wheat crops. Ann. Bot. 1994, 74, 397-407. [CrossRef]

34. Tarakanovas, P.; Raudonius, S. Statistical Analysis of Agronomic Research Data Using Computer Programs Anova, Stat, Split-Plot from the Package Selection and Irristat: A Methodological Tool for Master's and Doctoral Students of the Faculty of Agronomy; Akademija: Kaunas, Lithuania, 2003; p. 58.

35. Schmieder, K.; Dienst, M.; Ostendorp, W. Effects of the extreme flood in 1999 on the spatial dynamics and stand structure of the reed belts in Lake Constance. Limnologica 2002, 32, 131-146. [CrossRef]

36. Weilhoefer, C.L.; Williams, D.; Nguyen, I.; Jakstis, K.; Fischer, C. The effects of reed canary grass (Phalaris arundinacea L.) on wetland habitat and arthropod community composition in an urban freshwater wetland. Wetl. Ecol. Manag. 2017, 25, 159-175. [CrossRef]

37. Rancane, S.; Karklins, A.; Lazdina, D.; Berzins, P.; Bardule, A.; Butlers, A.; Lazdins, A. The evaluation of biomass yield and quality of Phalaris arundinacea and Festulolium fertilised with bio-energy waste products. Agron. Res. 2016, 14, 198-210.

38. Brencienè, V. Comparison of cereal grasses in the Western part of Lithuania. Žemdirbystè LŽI Mokslo Darbai 1995, 16-22.

39. Wachendorf, M.; Büchter, M.; Trott, H.; Taube, F. Performance and environmental effects of forage production on sandy soils. II. Impact of defoliation system and nitrogen input on nitrate leaching losses. Grass Forage Sci. 2004, 59, 56-68. [CrossRef]

40. Kukk, L.; Astover, A.; Roostalu, H.; Rossner, H.; Tamm, I. The Dependence of Reed Canary Grass (Phalaris arundinacea L.) Energy Efficiency and Profitability on Nitrogen Fertilization and Transportation Distance. Agron. Res. 2010, 8, $123-133$.

41. LAND 43-2013. Norms for Combustion Plants Emissions, 2013; Lithuanian Department of Standardization: Vilnius, Lithuania, 2013. (In Lithuanian) 